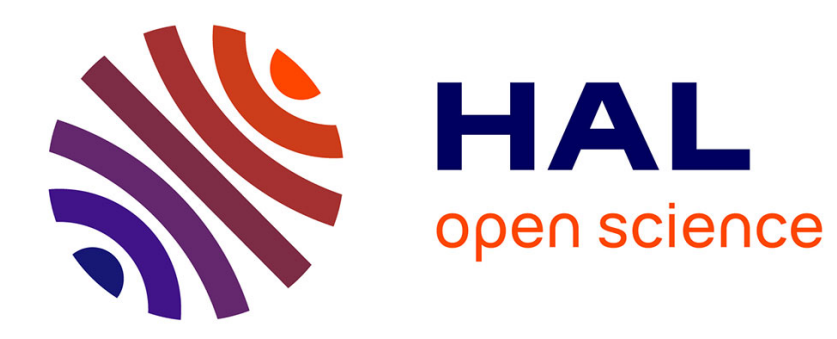

\title{
Obesity, growth hormone and weight loss
}

\author{
Michael Højby Rasmussen
}

\section{To cite this version:}

Michael Højby Rasmussen. Obesity, growth hormone and weight loss. Molecular and Cellular Endocrinology, 2009, 316 (2), pp.147. 10.1016/j.mce.2009.08.017 . hal-00550245

\section{HAL Id: hal-00550245 \\ https://hal.science/hal-00550245}

Submitted on 25 Dec 2010

HAL is a multi-disciplinary open access archive for the deposit and dissemination of scientific research documents, whether they are published or not. The documents may come from teaching and research institutions in France or abroad, or from public or private research centers.
L'archive ouverte pluridisciplinaire HAL, est destinée au dépôt et à la diffusion de documents scientifiques de niveau recherche, publiés ou non, émanant des établissements d'enseignement et de recherche français ou étrangers, des laboratoires publics ou privés. 


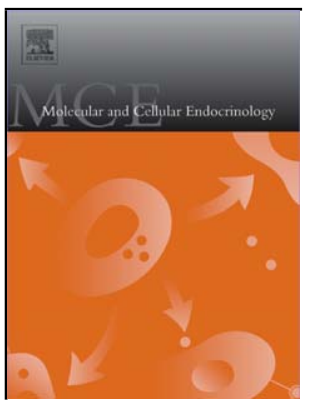




\section{Obesity, growth hormone and weight loss}

Michael Højby Rasmussen

Department of Endocrinology, Hvidovre Hospital, University of Copenhagen, DK-2650, Denmark

Key words: Obesity, Growth hormone, Weight loss, Insulin-like growth factor

\section{Correspondence to:}

Dr. Michael Højby Rasmussen MD, PhD, MSc

Langs Hegnet $52 \mathrm{~B}$,

Kongens Lyngby, DK-2800, Denmark

Tel. +45 30791619

E-mail:mhr@dadlnet.dk 


\begin{abstract}
Growth hormone $(\mathrm{GH})$ is the most important hormonal regulator of postnatal longitudinal growth in man. In adults GH is no longer needed for longitudinal growth. Adults with growth hormone deficiency (GHD) are characterised by perturbations in body composition, lipid metabolism, cardiovascular risk profile and bone mineral density. It is well established that adult GHD usually is accompanied by an increase in fat accumulation and GH replacement in adult patients with GHD results in reduction of fat mass and abdominal fat mass in particular. It is also recognized that obesity and abdominal obesity in particular results in a secondary reduction in GH secretion and subnormal insulin-like growth factor-I (IGF-I) levels. The recovery of the GH IGF-I axis after weight loss suggest an acquired defect, however, the pathophysiologic role of GH in obesity is yet to be fully understood. In clinical studies examining the efficacy of GH in obese subjects very little or no effect are observed with respect to weight loss, whereas GH seems to reduce total and abdominal fat mass in obese subjects. The observed reductions in abdominal fat mass are modest and similar to what can be achieved by diet or exercise interventions.
\end{abstract}




\section{Introduction}

Human growth hormone $(\mathrm{GH})$ is a mixture of peptides, the major physiologic and bioactive component being a $22 \mathrm{kDa}$ polypeptide chain of 191 amino acids secreted by the anterior pituitary gland (35). In man GH is secreted episodically in a pulsatile fashion. The main regulatory hormones of GH are two hypothalamic peptide hormones: GH releasing hormone (GHRH) a 44 amino-acid peptide required for the initiation of GH pulses and somatostatin an inhibitory peptide which modulates the amplitude of GH pulses. However, several brain transmitter pathways as well as sleep and several other factors seem to be involved in GH regulation, suppressing or stimulating GH release by influencing GHRH or somatostatin (35).

GH exerts biological effects directly on target cells by binding to cell membrane receptors or/and through insulin-like growth factor-I (IGF-I). According to the general somatomedin hypothesis, the effect of GH on the liver is to generate IGF-I, which is secreted into the bloodstream and delivered to the target tissues. Although the liver is believed to be the principal source of circulating IGF-I, IGF-I seems to be synthesized in most organs and released by paracrine as well as autocrine mechanisms (45). GH plays a major role in controlling longitudinal growth in children and is generally regarded as an anabolic factor, yet it has both anabolic and catabolic actions on different tissues in the human body $(49,59)$. For example, GH stimulates protein synthesis in muscle (109a), whereas in fat tissue it promotes lipolysis (49).

Adults with growth hormone deficiency (GHD) are characterised by perturbations in body composition, lipid metabolism, cardiovascular risk profile and bone mineral density $(6,18,97)$ and an increased risk of cardiovascular disease risk has also been reported in young overweight and obese women with impaired GH levels (96). It is well established that adult GHD usually is accompanied by an increase in fat accumulation and GH replacement in adult patients with GHD results in reduction of fat mass and abdominal fat mass in particular $(5,7,14,19,33,57,80,83,98)$. It is 
also recognized that abdominal obesity results in a secondary reduction in GH secretion reversible with weight loss $(70,98)$, the reasons for the reduced GH secretion are yet to be fully understood. However, whereas GH replacement in patients with GHD leads to specific depletion of intraabdominal fat, the administration of GH to obese individuals does not seem to result in a consistent reduction or redistribution in body fat (82). Although the administration of GH to obese subjects has only led to equivocal results (82), it still remains a plausible metabolic candidate according to more recent studies $(1,2,4,28,37,66)$. It is the intention of this review to present the current knowledge on the pathophysiology of the GH-IGF-I axis related to obesity and an overview of clinical studies examining the effect of GH on weight loss and body composition in obese subjects.

\section{The GH-Insulin-Like-Growth-Factor-I (IGF-I) Axis in Obesity}

In obese subjects the GH secretory response to a variety of stimuli (e.g. insulininduced hypoglycaemia, arginine, GHRH-arginine, sleep and exercise) is impaired compared to normal subjects $(56,69,70,72,74)$. The spontaneous GH secretion is decreased $(70,98)$ and GH clearance increased (54). It has been reported that an increase in each unit of BMI at a given age reduces the daily $\mathrm{GH}$ secretion by $6 \%$ (42).

The mechanism responsible for the altered GH secretion in obesity is largely unsettled. It has been hypothesized that a relatively increased amount of free IGF-I could be responsible for an enhanced feedback inhibition of GH release in obese subjects which could be a simple mechanism by which GH secretion is diminished in obesity (see below). Several other mechanisms have been proposed explaining the impaired GH release. For example, FFA may influence GH release negatively; however, a causal relationship between FFA and decreased GH secretion in obesity has not been proven. Elevated insulin levels seem capable of reducing GH release and the hyperinsulinemia which is a frequent finding in obesity could be related to the 
impaired GH secretion (15). Further, it has been proposed that the reduced GH secretion in obesity may be due to diminished GH pituitary reserves. However, this hypothesis seems unlikely by the observation of a massive GHRH and GH-releasing peptide-6 induced GH release in obese subjects (17) suggesting a marked somatoroph secretory capacity in obesity and arguing against reduced stores of GH, as the explanation of the impaired GH secretion in obesity. The cause for the increased GH clearance is also puzzling, especially seen in the light of increased growth hormone GH-binding protein (GHBP) observed in obesity (see below). To what extent subnormal GH secretion and increased clearance may contribute to preserve the obese state is unknown. However, as described previously GH plays an important role in the maintenance of normal body composition in as much as GHD adults have increased adiposity which can be corrected by GH administration.

GH is bound to a high affinity circulating GHBP. In man, there is evidence that GHBP is derived from proteolytical cleavage of the extracellular domain of the GH receptor and may reflect GH receptor status (55). Several studies have reported that GHBP levels are increased in obesity $(27,41,71)$ and a direct relationship between abdominal adiposity and GHBP concentration has been observed (71). The physiological significance of increased GHBP in obesity is presently unknown. It would be reasonable to speculate that the increased GHBP levels in obesity serve to prolong the biological $t^{1} / 2$ of $\mathrm{GH}$. However, deconvolution analysis of concentration profiles reveals that the clearance of $\mathrm{GH}$ is accelerated in obesity and might contribute to the hyposomatropism in this condition (98). If circulating levels of GHBP reflect GH receptor density, an alternative explanation might be that the greater density of tissue receptors acts to sequester GH more avidly from the circulation, and this phenomenon might represent tissue adaptation to reduced GH output in obesity. However, if this is so, then increased GH sensitivity and increased adipose tissue responsiveness to $\mathrm{GH}$ would be expected. This seems not to be the case, as the lipolytic action of $\mathrm{GH}$ is similar in abdominally obese and normal weight subjects. Thus, the alternative hypothesis is 
that the reduced GH levels, given normal adipose tissue responsiveness, blunts lipolysis in abdominally obese subjects and therefore contributes to the development of an increased amount of abdominal fat which then again increase the risk of developing abdominal obesity associated diseases. In favour of this hypothesis is that abdominally obese subjects have numerous metabolic features in common with GHD patients. For example, both conditions are associated with insulin resistance, hypercholesterolemia, reduced HDL and hypertension.

IGF-I is a GH dependent polypeptide, which mediates some of the actions of GH. Despite the reduced levels of GH in obesity, studies have reported conflicting data with regards to the levels of IGF-I. However, the majority of studies report IGF-I to be low-normal or low (47) in obese subjects compared to lean normal subjects. In accordance with this an inverse relationship between IGF-I and indices of fat mass distribution has been demonstrated (68). The IGF-axis is of increasing interest due to recent reports suggesting that low IGF-I levels are closely linked to the pathogenesis of T2DM and cardiovascular disease $(44,46,81)$.

Free (biologically active) IGF-I accounts for less than $1 \%$ of the total circulating amount of IGF-I. However, free IGF-I is believed to be responsible for the bioactivity on target tissue $(31,45)$. It has been hypothesized that a relatively increased amount of free IGF-I could be responsible for an enhanced feedback inhibition of GH release in obese subjects and thereby be a simple mechanism by which GH secretion is diminished in obesity $(29,70)$. Free IGF-I has been reported to be relatively increased in one group of obese men and women (30) and two studies have reported increased free IGF-I levels in obese men $(29,61)$. In contrast, other studies have observed normal $(63,75)$ to low $(34)$ free IGF-I levels in obese men and women. It could be argued that these discrepancies can be accounted for by methodological differences as free IGF-I determinations are technically difficult and the observed between-study heterogeneity could be a result of differences in the assay used. However, both ultrafiltrated free IGF-I as well as dissociated free IGF-I levels 
have been measured and both found to be significantly decreased in obese women (73). This is in accordance with the previous reported decreased IGF-I/IGFBP-3 molar ratio, a rough estimate of free, biologically active IGF-I, in obesity $(26,70)$ and the normalisation after diet-induced or surgical-induced weight loss consistent with the transient GH-deficient state $(26,70)$. The previous observed differences in measured values of fasting free IGF-I could be due to diurnal induced variations in free IGF-I, IGFBP-1 levels, fasting induced or other hour-to-hour factors influencing the amount of free IGF-I. Thus, in a recent study both 24-h diurnal mean free IGF-I and basal free IGF-I levels were measured and both were found to be decreased in the obese women compared to non-obese women (73). Therefore, it seems very unlikely that circulating free IGF-I should mediate the impaired 24-hour GH release as previously hypothesized.

One possible explanation for the different free IGF-I levels observed in obese subjects might be the type of fat distribution, since visceral fat mass, rather than adiposity per se, has been reported to correlate inversely to circulating total IGF-I levels $(21,53,60,68,70)$, and free IGF-I levels could also vary across categories of indices of adiposity. Free IGF-I levels correlate inversely with different measures of obesity and body composition and with the strongest relationship to waist circumference and visceral fat mass. Thus, it seems that obesity, and visceral obesity in particular, is interlinked to decreased free IGF-I levels in alignment with the previously reported decreased total IGF-I levels. The mechanism subserving this link is presently not known. Recent data suggest that inflammatory mediators may play a role in inducing reduced IGF-I bioactivity (90) and in recent years adipose tissue has emerged as an important source of pro-inflammatory mediators (51). The question of whether these mediators play a role in the IGF-I/IGF-binding protein system in obesity requires future study. However, the finding of low circulating free IGF-I in visceral obesity (73) is of dual interest because visceral fat mass plays a crucial role in the 
development of obesity-related diseases and recent reports suggest that low IGF-I levels are further linked to the pathogenesis of T2DM and cardiovascular disease $(44,45,81)$.

\section{Effect of caloric restriction and weight loss on the GH-IGF-I axis in obesity}

Caloric restriction applied for a relatively short-term usually increases the $\mathrm{GH}$ release significantly in normal weight subjects (38); however, this is significantly abolished in obese subjects $(36,69)$. The lack of stimulation of GH release in obese subjects by diet may promote retention of fat mass. However, studies have demonstrated that apparently all the defects in the GH IGF-I axis in obesity are reversible with diet-induced and surgical induced large weight loss $(20,56,70)$. The recovery of the GH IGF-I axis after weight loss suggest an acquired defect, rather than a pre-existing disorder. The impaired GH IGF-I axis may, however, act toward expansion and maintenance of fat mass and contribute to perpetuation of the obese state.

\section{Obesity, Growth Hormone Deficiency and Body Composition}

Obesity as such is a serious health hazard, and the various risks associated with obesity seem related to abdominal fat accumulation in particular (10). The heterogeneity of obesity may explain why not every obese subject is characterized by chronic complications. In this regard, body fat distribution, especially intra-abdominal adipose tissue accumulation, has been found to be a key factor of diabetogenic, atherogenic and inflammatory metabolic abnormalities increasing the risk of T2DM and cardiovascular disease (10). It has recently been demonstrated that abdominal obesity was independently associated with an increased risk of coronary heart disease and T2DM independently of overall adiposity $(12,22,23)$.

The fact that GH induces lipolysis in humans has been known for many years (67). 
Children with GHD have increased levels of body fat which is more pronounced on the trunk than on the limbs. When GHD children are treated with GH, body fat returns to normal after a few months of treatment. Adults with GHD have abnormal body composition with increased amounts of body fat, especially abdominal body fat. GH treatment in GHD adults has consistently been shown to promote growth of lean tissue while reducing fat mass $(48,80,83,100)$. The reduction of fat mass is a consistent finding in GH treated GHD adults and independent of the methodologies used. However, the magnitude of the change in fat mass varies considerably according to the different methods applied (9). These encouraging effects of GH have generated interest in the efficacy of using $\mathrm{GH}$ in the treatment of obesity.

\section{Effect of growth hormone therapy on body weight and body composition}

In a literature search 19 randomised controlled studies investigating GH therapy in obese subjects were identified (Table 1). Two trials $(79,89)$ were excluded due to lack of placebo control and five trials were excluded as they fell outside the category of obese subjects $(8,11,32,58,91)$. In addition, three non-controlled studies $(16,87,88)$ and three trials investigating GH treatment of obese children were excluded for further analysis $(3,25,50)$. In only two of the studies pre- vs. post-treatment changes in body weight were observed to be greater than placebo (Table 1). Thus, in the vast majority of the investigations no significant effect on body weight was reported and based on these results significant decreases in body weight cannot be expected during GH treatment in obese subjects. The evidence from the studies support to some extent GH as being effective in reducing fat mass and abdominal/visceral fat mass in obese subjects in as much as 11 of the 19 significant pre- vs. post-treatment reductions in total fat mass and/or abdominal/ visceral fat mass. However, it has to be acknowledged that only seven of these studies reported significant reductions when compared to placebo (Table 1). 
A simple comparison revealed that in the studies reporting a significant effect on loss of fat mass the mean duration of GH treatment was considerably longer compared to the studies showing no significant effect. Thus, the impact of GH on fat mass seems to depend on treatment duration of 12 weeks or more as only few studies with less than 12 weeks treatment duration reported reduction in fat mass. When analysing the studies of medium to long-term duration separately, reductions in total fat mass and or abdominal fat mass were observed and occurred in studies covering a broad dose range. Although the GH dose that may be more efficacious in obese subjects has not been established, the studies of more than 12 weeks duration indicate that a dose in the range of the current average dose for GH replacement in GHD adults or even lower may be suitable. In future studies rather lower doses than excessively high GH doses should be considered in order to minimize the $\mathrm{GH}$ induced hyperinsulinemia which may oppose the lipolytic effect of GH in obese subjects. It has been suggested that the mechanism behind this is that lower GH doses exert insulin-like effects (101), whereas a high dose of GH is more likely to be associated with deterioration in insulin sensitivity. It could also be speculated that titration and a lower dose may increase compliance due to reduction in the number of dose-related side-effects.

If exclusively analysing the studies with treatment duration of a minimum of 12 weeks, nine out of 11 studies reported significant pre- vs. post-treatment reductions in total fat mass and/or abdominal/visceral fat mass and six of these studies reported significant reductions when compared to placebo (Table 2). In six of these studies a significant reduction in visceral adipose tissue ranging from 5-34\% as measured by CT were observed (Table 2). In comparison other interventions that reduce body weight in obese subjects, such as caloric restriction, very-low calorie diet, or exercise produced reduction in visceral adiposity ranging from 9-49\% (85). Seven of the nine studies with a treatment duration of minimum 12 weeks showed that changes in body fat mass 
and abdominal fat mass can occur with GH treatment compared to placebo in the absence of significant reduction in body weight (Table 2).

It is of interest that also smaller GH fragments stimulate energy expenditure and induce weight loss in animals (39). Intact GH may induce insulin resistance, at least initially. It is possible that the development of GH fragments (with predominant activity directed at fat) may potentially improve body composition without adversely affecting glucose metabolism. This is of potential interest in the treatment of obese subjects and in subjects with metabolic syndrome. AOD9604, a growth hormone fragment developed to selectively stimulate prolipid mobilizing and lipid oxidation portions, has shown promise in animal (39) and early clinical phase 1 studies (40). The clinical study, a 12-week phase II study, showed that 34 patients treated with low-dose oral AOD9604 experienced significant weight loss and improvement in glucose tolerance compared with the 37 placebo-treated patients (40).

Traditionally, in the management of obesity the primary goal is weight loss. However, from a medical point of view measures of GH induced body composition changes are more meaningful than weight loss since abdominal/visceral obesity in particular are related to the risk of increased morbidity and mortality in obese subjects than obesity per see (65). Abdominal/visceral fat is more important than peripheral fat depots for the adverse consequences of obesity $(10,13)$. It is important to recognize that it is the amount of adipose tissue, especially visceral adipose tissue that confers the negative impact of obesity on health risk factors, whereas peripheral adipose tissue might have a protective role against arteriosclerosis (94). It is a fact that among equally overweight/obese subjects carefully matched for their level of total body fat, patients with a selective excess of visceral adipose tissue are at a substantially increased risk of showing the welldescribed abnormalities of insulin resistance. For this reason, the reduction in abdominal/visceral fat 
depots and increased/unchanged lean body mass could be considered beneficial, even though no major weight loss was achieved.

\section{Conclusions}

There is now sufficient evidence to conclude that the GH-IGF-I axis in obesity is impaired with decreased GH secretion and subnormal IGF-I levels. The recovery of the GH IGF-I axis after weight loss suggest an acquired defect, however, the fully understanding of the mechanisms subserving the obese state of hyposomatotropism remain yet to be revealed in further investigation. The clinical studies examining the efficacy of GH in obese subjects demonstrated very little or no evidence with respect to weight loss by GH therapy of obese subjects. More evidence exists with respect to the effect in reducing total and abdominal fat mass in obese subjects. The observed reductions in abdominal fat mass were modest and similar to what can be achieved by diet or exercise interventions. It is unproven whether the GH induced reductions in fat mass are beneficial for obese subjects in the long-term. 
Table 1: The effect of GH on weight and body composition

\begin{tabular}{|c|c|c|c|c|c|c|c|}
\hline Reference & $\begin{array}{c}\text { Age } \\
\begin{array}{c}\text { Mean } \pm \text { SD } \\
\text { (range) }\end{array}\end{array}$ & $\frac{\begin{array}{c}\text { Body } \\
\text { Composition }\end{array}}{\text { Method }}$ & $\frac{\text { Total }}{\underline{\text { FM }}}$ & $\frac{\text { Abdomina }}{\underline{F M}}$ & LBM & $\frac{\text { Body }}{\text { Weight }}$ & $\frac{\text { Duration/ }}{\underline{\text { Dose }}}$ \\
\hline Albert et al. 2004 & $35.0 \pm 6.0$ & DEXA & $\downarrow *$ & $\downarrow^{*}$ & $\rightarrow$ & $\downarrow *$ & $\begin{array}{c}6 \text { months/ } \\
3.8 / 6.0 \mu \mathrm{g} / \mathrm{kg} / \mathrm{d}\end{array}$ \\
\hline Ahn et al 2006 & $53.1 \pm 7.2$ & CT & $\downarrow$ & $\downarrow^{*}$ & $\uparrow$ & $\rightarrow$ & $\begin{array}{l}12 \text { weeks/ } \\
\sim 500 \mu \mathrm{g} / \mathrm{d}\end{array}$ \\
\hline Attallah et al. 2005 & $55.1+10.5$ & CT & & $\downarrow *$ & & $\rightarrow$ & $\begin{array}{l}40 \text { weeks/ } \\
8.0 \mu \mathrm{g} / \mathrm{kg} / \mathrm{d}\end{array}$ \\
\hline Drent et al. 1995 & $39.1 \pm 7.9$ & BIA, TBP & $\rightarrow$ & & $\rightarrow$ & & $\begin{array}{l}8 \text { weeks/ } \\
2000 \mu \mathrm{g} / \mathrm{d}\end{array}$ \\
\hline Franco et al. 2005 & $58(51-63)$ & CT & $\rightarrow$ & $\downarrow^{*}$ & $\rightarrow$ & $\rightarrow$ & $\begin{array}{c}12 \text { months/ } \\
670 \mu \mathrm{g} / \mathrm{d}\end{array}$ \\
\hline Halpern et al. 2006 & $35.9 \pm 7.5$ & DEXA & $\downarrow$ & & $\rightarrow$ & $\downarrow *$ & $\begin{array}{l}13 \text { weeks } / \\
50 \mu \mathrm{g} / \mathrm{kg} / \mathrm{d}\end{array}$ \\
\hline Johannsson et al. 1997 & $58(48-66)$ & CT & $\downarrow$ & $\downarrow$ & $\rightarrow$ & $\rightarrow$ & $\begin{array}{l}39 \text { weeks } \\
9.5 \mu \mathrm{g} / \mathrm{kg} / \mathrm{d}\end{array}$ \\
\hline Jørgensen et al. 1994 & $30.4 \pm 2.4$ & DEXA & $\downarrow *$ & & & & $\begin{array}{c}5 \text { weeks/ } \\
30 \mu \mathrm{g} / \mathrm{kg} / \mathrm{d}\end{array}$ \\
\hline Kim et al. 1998 & $37.5 \pm 9.0$ & $\mathrm{BIA}, \mathrm{CT}$ & $\downarrow$ & $\downarrow$ & $\rightarrow$ & $\rightarrow$ & $\begin{array}{l}12 \text { weeks/ } \\
10 \mu g / k g / d\end{array}$ \\
\hline Nam et al. 2001 & $47.3 \pm 6.2$ & BIA, CT & $\downarrow *$ & $\downarrow *$ & $\uparrow$ & $\rightarrow$ & $\begin{array}{l}12 \text { weeks } / \\
10 \mu \mathrm{g} / \mathrm{kg} / \mathrm{d}\end{array}$ \\
\hline Nørrelund et al. 2000 & $36 \pm 4.2$ & DEXA & $\longrightarrow$ & & $\rightarrow$ & & $\begin{array}{c}4 \text { weeks/ } \\
10-27 \mu \mathrm{g} / \mathrm{kg} / \mathrm{d}\end{array}$ \\
\hline Richelsen et al. 1994 & $32.0 \pm 3.1$ & CT, DEXA & $\downarrow$ & $\downarrow$ & $\uparrow$ & $\uparrow$ & $\begin{array}{c}5 \text { weeks } / \\
30 \mu \mathrm{g} / \mathrm{kg} / \mathrm{d}\end{array}$ \\
\hline Richelsen et al. 2000 & $35.3 \pm 3.8$ & DEXA & $\rightarrow$ & & & & $\begin{array}{c}4 \text { weeks/ } \\
10-27 \mu \mathrm{g} / \mathrm{kg} / \mathrm{d}\end{array}$ \\
\hline Pasarica et al. 2007 & $50 \pm 7$ & DEXA & $\downarrow *$ & $\downarrow *$ & $\uparrow$ & $\uparrow$ & $\begin{array}{l}26 \text { weeks/ } \\
10 \mu \mathrm{g} / \mathrm{kg} / \mathrm{d}\end{array}$ \\
\hline Skaggs et al. 1991 & $34(29-50)$ & UW & $\downarrow$ & & $\rightarrow$ & $\rightarrow$ & $\begin{array}{c}4 \text { weeks/ } \\
240 \mu \mathrm{g} / \mathrm{kg} / \text { week }\end{array}$ \\
\hline Snyder et al. 1988 & $20-54$ & UW & $\rightarrow$ & & & $\rightarrow$ & $\begin{array}{l}10 \text { weeks/ } \\
50 \mu \mathrm{gg} / \mathrm{kg} / \mathrm{d}\end{array}$ \\
\hline Tagliaferri et al. 1998 & $25.4 \pm 1.1$ & DEXA & $\rightarrow$ & & $\rightarrow$ & $\rightarrow$ & $\begin{array}{c}4 \text { weeks/ } \\
50 \mu \mathrm{g} / \mathrm{kg} / \mathrm{d}\end{array}$ \\
\hline Thompson et al. 1998 & $67(59-79)$ & DEXA & $\rightarrow$ & & $\uparrow$ & $\rightarrow$ & $\begin{array}{r}12 \text { weeks/ } \\
50 \mu \mathrm{g} / \mathrm{kg} / \mathrm{d}\end{array}$ \\
\hline Taaffe et al. 2000 & $67.1 \pm 5.2$ & DEXA & & $\rightarrow$ & & & $\begin{array}{l}12 \text { weeks/ } \\
50 \mu \mathrm{g} / \mathrm{kg} / \mathrm{d}\end{array}$ \\
\hline
\end{tabular}

* Significant change compared to placebo 
Table 2: The clinical studies with a duration of treatment of at least 12 weeks. Effects of GH on weight and body composition

\begin{tabular}{|c|c|c|c|c|c|c|c|c|}
\hline Reference & $\frac{\text { Sub }}{M}$ & cts & $\frac{\begin{array}{c}\text { Body } \\
\text { Composition }\end{array}}{\text { Method }}$ & $\frac{\frac{\text { Total }}{\text { FM }}}{\text { mean } \pm S D}$ & $\frac{\text { Abdominal }}{\underline{\mathrm{FM}}}$ & LBM & $\begin{array}{l}\text { Body } \\
\text { Weight }\end{array}$ & $\frac{\text { Duration }}{\text { (Dose) }}$ \\
\hline Albert et al. 2004 & 12 & 27 & DEXA & $\begin{array}{c}\downarrow^{*} \\
2.89 \mathrm{~kg} \\
\pm 3.76\end{array}$ & $\begin{array}{c}\downarrow^{*} \\
1.5 \mathrm{~kg}^{* *} \approx 8 \%\end{array}$ & $\rightarrow$ & $\begin{array}{c}\downarrow^{*} \\
2.4 \mathrm{~kg}^{* *} \approx 2.4^{\prime}\end{array}$ & $\begin{array}{c}6 \text { months } \\
(3.8 / 6.0 \mu \mathrm{g} / \mathrm{kg} / \mathrm{d})\end{array}$ \\
\hline Ahn et al 2006 & 12 & 12 & CT & $\begin{array}{c}\downarrow \\
4.0 \% \\
\pm 3.2\end{array}$ & $\begin{array}{c}\downarrow * \\
16.4 \mathrm{~cm}^{2} \\
\pm 19.2 \approx 10 \%\end{array}$ & $\uparrow$ & $\rightarrow$ & $\begin{array}{l}12 \text { weeks } \\
(\sim 500 \mu \mathrm{g} / \mathrm{d})\end{array}$ \\
\hline Attallah et al. 2005/7 & 51 & 30 & CT & & $\begin{array}{c}\downarrow^{*} \\
23.9 \mathrm{~cm}^{2} \\
\pm 7.4 \approx 13 \%\end{array}$ & & $\rightarrow$ & $\begin{array}{c}40 \text { weeks } \\
(8.0 \mu \mathrm{g} / \mathrm{kg} / \mathrm{d})\end{array}$ \\
\hline Franco et al. 2005 & & 40 & CT & $\rightarrow$ & $\begin{array}{c}\downarrow^{*} \\
6.6 \mathrm{~cm}^{2 * *} \approx 6 \%\end{array}$ & $\rightarrow$ & $\rightarrow$ & $\begin{array}{c}12 \text { months } \\
(670 \mu \mathrm{g} / \mathrm{d})\end{array}$ \\
\hline Halpern et al. 2006 & 40 & & DEXA & $\begin{array}{c}\downarrow \\
9.5 \% \\
\pm 7.9\end{array}$ & & $\rightarrow$ & $\begin{array}{c}\downarrow^{*} \\
3.5 \mathrm{~kg}^{* *} \approx 2.9^{\prime}\end{array}$ & $\begin{array}{c}13 \text { weeks } \\
(50.0 \mu \mathrm{g} / \mathrm{kg} / \mathrm{d})\end{array}$ \\
\hline Johannsson et al. 1997 & 30 & & CT & $\begin{array}{c}\downarrow \\
9.2 \% \\
\pm 2.4^{* * *}\end{array}$ & $\begin{array}{c}\downarrow \\
14.5 \% \\
\pm 3.8^{* * \star}\end{array}$ & $\rightarrow$ & $\rightarrow$ & $\begin{array}{c}39 \text { weeks } \\
(9.5 \mu \mathrm{g} / \mathrm{kg} / \mathrm{d})\end{array}$ \\
\hline Kim et al. 1998 & 2 & 22 & $\mathrm{BIA}, \mathrm{CT}$ & $\begin{array}{c}\downarrow \\
1.0 \mathrm{~kg} \\
\pm 0.5\end{array}$ & $\begin{array}{c}\downarrow \\
31.5 \mathrm{~cm}^{2} \\
\pm 2.3 \approx 34 \%\end{array}$ & $\rightarrow$ & $\rightarrow$ & $\begin{array}{c}12 \text { weeks } \\
(10.0 \mu \mathrm{g} / \mathrm{kg} / \mathrm{d})\end{array}$ \\
\hline Nam et al. 2001 & 10 & 8 & BIA, CT & $\begin{array}{c}\downarrow * \\
1.0 \mathrm{~kg} \\
\pm 0.4\end{array}$ & $\begin{array}{c}\downarrow * \\
39.5 \mathrm{~cm}^{2} \\
\pm 3.3 \approx 28 \%\end{array}$ & $\uparrow$ & $\rightarrow$ & $\begin{array}{c}12 \text { weeks } \\
(9.0 \mu \mathrm{g} / \mathrm{kg} / \mathrm{d})\end{array}$ \\
\hline Pasarica et al. 2007 & 30 & & CT, DEXA & $\begin{array}{c}\downarrow * \\
1.8 \% \\
\pm 0.3\end{array}$ & $\begin{array}{c}\downarrow^{*} \\
0.6 \mathrm{~kg} \\
\pm 0.13 \approx 5 \%\end{array}$ & $\uparrow$ & $\begin{array}{c}\uparrow \\
2 \mathrm{~kg}^{* *} \approx 1.9 \%\end{array}$ & $\begin{array}{c}26 \text { weeks } \\
10 \mathrm{mg} / \mathrm{kg} / \mathrm{d}\end{array}$ \\
\hline Thompson et al. 1998 & & 16 & DEXA & $\rightarrow$ & & $\uparrow$ & $\rightarrow$ & $\begin{array}{c}12 \text { weeks } \\
(50 \mu \mathrm{g} / \mathrm{kg} / \mathrm{d})\end{array}$ \\
\hline Taaffe et al. 2000 & & 14 & DEXA & & $\rightarrow$ & & & $\begin{array}{c}12 \text { weeks } \\
(50 \mu \mathrm{g} / \mathrm{kg} / \mathrm{d})\end{array}$ \\
\hline
\end{tabular}

* Significant change compared to placebo

**No range provided

***mean \pm SEM 


\section{References:}

1. Albert SG, Mooradian AD. Low-dose recombinant human growth hormone as adjuvant therapy to lifestyle modifications in the management of obesity. J Clin Endocrinol Metab 2004;89:695-701.

2. Ahn CW, Kim CS, Nam JH, et al. Effects of growth hormone on insulin resistance and atherosclerotic risk factors in obese type 2 diabetic patients with poor glycaemic control. Clin Endocrinol 2006;64:444-449.

3. Ardizzi A., Grugni G., Guzzaloni G., Moro D., Morabito F. Effects of protracted rhGH administration on body composition and intermediate metabolism in juvenile obesity. Acta Med Auxol 1996;28:103-109.

4. Attallah HY, Friedlander AL, Nini-Murcia M, Hoffmann AR. Effects of Growth hormone and pioglitazone in viscerally obese adults with impaired glucose tolerance: A factorial clinical trial. PLoS Clin Trials 2007;2(5):e21. doi:10.1371/journal.pctr.0020021.

5. Bengtsson BA, Eden S, Lonn L, Kvist H, Stokland A, Lindstedt G, Bosaeus I, Tolli J, Sjostrom L, Isaksson OG. Treatment of adults with growth hormone deficiency with recombinant human GH. J Clin Endocrinol Metab 1993;76: 309-317.

6. Beshyah SA, Henderson A, Niththyanathan R, Sharp P, Richmond W, Johnston D. Metabolic abnormalities in growth hormone-deficient adults. II. Carbohydrate tolerance and lipid metabolism. Endocrinol Metab 1994;1:173-180.

7. Binnerts A, Swart GR, Wilson JHP, et al. The effect of growth hormone administration in growth hormone deficient adults on bone, protein, carbohydrate and lipid homeostasis, as well as body composition. Clin Endocrinol 1992;37: 79-87.

8. Blackman MR, Sorkin JD, Münzer T. et al. Growth hormone and sex steroid administration in healthy aged women and men: a randomized controlled trial. JAMA 2002;288:2282-2292.

9. Bosaeus I, Johansson G, Rosén T, et al. Comparison of methods to estimate body fat in growth hormone deficient adults. Clin Endocrinol 1996;44:395-402.

10. Bray GA. Medical Consequences of Obesity. J Clin Endocrinol Metab 2004;2583-2589. 
11. Brill KT, Weltman AL, Gentili A, et al. Single and combined effects of growth hormone and testosterone administration on measures of body composition, physical performance, mood, sexual function, bone turnover, and muscle gene expression in healthy older men. J Clin Endocrinol Metab 2002;87:5649-5657.

12. Brochu M, Starling RD, Tcernof A, Matthews DE, Garcia-Rubi E, et al. Visceral adipose tissue is an independent correlate of glucose disposal in older obese postmenopausal women. J Clin Endocrinol Metab 2000;85:2378-2384.

13. Busetto L. Visceral obesity and the metabolic syndrome: effects of weight loss. Nutr Metab Cardiovasc Dis 2001;11:195-204.

14. Chrisolidou A, Beshyah S, Rutherford O, et al., Effects of seven years of growth hormone replacement therapy in hypopituitary adults. J Clin Endocrinol Metab 2000;85:3762-3769.

15. Clasey JL, Weltman A, Patrie J, et al. Abdominal visceral fat and fasting insulin are important predictors of 24-hour GH release Independent of age, gender, and other physiological factors. J Clin Endocrinol Metab 2001;86:3845-3852.

16. Clemmons DR, Snyder DK, Williams R, Underwood LE. Growth hormone administration conserves lean body mass during dietary restriction in obese subjects. J Clin Endocrinol Metab 1987; 64:878883.

17. Cordido F, Penalva A, Diequez C, Casanueva FF. Massive growth hormone (GH) discharge in obese subjects after the combined administration of GH-releasing hormone and GHRP-6: evidence for a marked somatotroph secretory capacity in obesity J Clin Endocrinol Metab 1993;76:819-823.

18. Consensus guidelines for the diagnosis and treatment of adults with growth hormone deficiency: summary statement of the Growth Hormone Research Society workshop on adult growth hormone deficiency. J Clin Endocrinol Metab 1998;83: 379-381.

19. Cummings DE, Merriam GR. Growth hormone therapy in adults. Annu Rev Med 54: 513-533, 2003. 
20. De Marinis L, Bianchi A, Mancini A, et al.. Growth hormone secretion and leptin in morbid obesity before and after biliopancreatic diversion: realtionships with insulin and body composition. J Clin Endocrinol Metab 2004;89:174-180.

21. De Pergola G, Zamboni GM, Pannacciulli N, et al. Divergent effects of short-term, very-low-calorie diet on insulin-like growth factor-I and insulin-like growth factor binding protein-3 serum concentrations in premenopausal women with obesity. Obes Res 1998;6:408-15.

22. Després JP, Lemieux I, Prud'homme D. Treatment of obesity: need to focus on high risk abdominally obese patients. BMJ 2001;322: 716-720.

23. Despres JP. Is visceral obesity the cause of the metabolic syndrome? Ann Med 2006;38:52-63.

24. Drent ML, Wever LD, Ader HJ, van der Veen EA. Growth hormone administration in addition to a very low calorie diet and an exercise program in obese subjects. Eur J Endocrinol 1995;132:565-572.

25. Eliman A, Norgren S, Marcus C. Effects of growth hormone treatemnt on the leptin sstem and body composition in obese prepubertal boys. Acta Paedr 2001;90:520-525.

26. Engström BE, Burman P, Holdstock C, Öhrval M, Sundbom M, Karlsson FA. Effects of gastric bypass on the GH/IGF-I axis in severe obesity - and a comparison with GH deficiency. Eur J Endocrinol 2006;154:53-9.

27. Fisker S, Physiology and pathophysiology of growth hormone-binding protein: methodological and clinical aspects. Growth Horm IGF Res 2006;161-28.

28. Franco C, Brandberg J, Lonn L, Andersson B, Bengtsson BA, Johannsson G. Growth hormone treatment reduces abdominal visceral fat in postmenopausal women with abdominal obesity: a 12month placebo-controlled trial. J Clin Endocrinol Metab 2005;90:1466-1474.

29. Frystyk J, Vestbo E, Skjærbæk C, Mogensen CE, Ørskov H. Free Insulin-like growth factors in human obesity. Metabolism 1995;44(Suppl 4):37-44.

30. Frystyk J, Skjaerbaek C, Vestbo E, Fisker A, Ørskov H. Circulating levels of free insulin-like growth factors in obese subjects: the impact of type 2 diabetes. Diabetes Metab Res Rev 1999;15:314-22.

31. Frystyk J. Free insulin-like growth factors - measurements and relationships to growth hormone secretion and glucose homeostasis. Growth Horm IGF Res 2004;14;337-75. 
32. Giannoulis MG, Sonksen PH, Umpleby M, et al. The effects of growth hormone and/or testosterone in healthy elderly men; a randomized controlled trial. J Clin Endocrinol Metab 2006;91:477-484.

33. Gibney J, Wallace JD, Spinks T, et al., The effects of 10 years of recombinant human growth hormone (GH) in adult GH-deficient patients. J Clin Endocrinol Metab 1999;84:2596-2602.

34. Gomez JM, Maravall FJ, Gomez N, Navarro MA, Casamitjana R, Soler J. The IGF-I system component concentrations that decrease with ageing are lower in obesity in relationship to body mass index and body fat. Growth Horm IGF Res 2004;14;91-6.

35. Godenberg N, Barkan A. Factor's regulating growth hormone secretion in humans. Endocrinol Metab Clin N Am 2007;36:37-55.

36. Grottoli S, Gauna C, Tassone F, et al. Both fasting-induced leptin reduction and GH increase are blunted in Cushing's syndrome and in simple obesity. Clin Endocrinol 2003;58;220-228.

37. Halpern A, mancini MC, Cercato C, Vilares SM, Costa AP. Effects of growth hormone on anthropometric and metabolic parameters in android obesity. Arquivos Brasileiros de Endocrinologia e Metabologia. 2006;50:68-73.

38. Hartman ML, Veldhuis JD, Johnsson ML lee MM, Alberti KG, Samojlik E, Thorner MO. Augumented growth hormone (GH) secretory burst frequency and amplitude mediate GH secretion during a two-day fast in normal men. J Clin Endocrinol Metab 1992;74:757-765.

39. Heffernan MA, Thornburn AW, Fam B, et al. Increase of fat oxidation and weight loss in obese mice caused by chronic treatment with human growth hormone or a modified C-terminal fragment. Int $\mathbf{J}$ Obes Relat Metab Disord. 2001;25:1442-9.

40. Herd C, Wittert G, Caterson I, et al. The effect of AOD9604 on weight loss in obese adults: results of a randomized, double-blind, placebo-controlled, multicenter study. 2005 Annual Scientific Meeting of the North American Association for the Study of Obesity, October 18, 2005, Vancouver, British Columbia, Canada.

41. Hochberg Z, Hertz P, Colin V, et al. The distal axis of growth hormone (GH) in nutritional disorders: GH-binding protein, insulin-like growth factor-I (IGF-I) and IGF receptors in obesity and anorexia nervosa. Metabolism 1992;41:106-112. 
42. Iranmanesh A, Lizarralde G, Veldhuis. Age and relative adiposity are specific negative determinants of the frequency and amplitude of growth hormone $(\mathrm{GH})$ secretory bursts and the half-life of endogenous GH in healthy men. J Clin Endocrinol Metab 1991;73:1081-1088.

43. Johannsson G, Marin P, Lonn L. et al. Growth hormone treatment of abdominally obese men reduces abdominal fat mass, improves glucose and lipoprotein metabolism, and reduces diastolic blood pressure. J Clin Endocrinol Metab 1997;82:727-734.

44. Johnsen SP, Hundborg HH, Sørensen HT, et al. Insulin-like growth factor (IGF) I, -II, and IGF binding protein-3 and risk of ischemic stroke. J Clin Endocrinol Metab 2005;90:5937-41.

45. Jones JI, Clemmons DR.. 1995 Insulin-like growth factors and their binding proteins: biological actions. Endocr Rev 1995;16:3-34

46. Juul A, Scheike T, Davidsen M, Gyllenborg J, Jørgensen T. Low serum insulin-like growth factor I is associated with increased risk of ischemic heart disease. Circulation 2002;106:939-44.

47. Juul A. Serum levels of insulin-like growth factor I and its binding proteins in health and disease. Growth Horm IGF Res 2003;13;113-70

48. Jørgensen JOL, Pedersen SA, Thuesen L, et al. Beneficial effect of growth hormone treatment in GH-deficient adults Lancet 1989;333:1221-1225.

49. Jørgensen JOL, Møller L, Krag, Billestrup N Christiansen JS. Effects of growth hormone on glucose and fat metabolism in human subjects. Endocrinol Metab Clin N Am 2007;36:75-87.

50. Kamel A., Norgren S., Elimam A., Danielsson P., Marcus C. Effects of growth hormone treatment in obese prepubertal boys. J Clin Endocrinol Metab 2000;85:1412-1419.

51. Kershaw EE, Flier JS. Adipose tissue as an endocrine organ. J Clin Endocrinol Metab 2004;89:254856.

52. Kim KR, Nam SY, Song YD, et al. Low-dose growth hormone treatment with diet restriction accelerates body fat loss, exerts anabolic effect and improves growth hormone secretory dysfunction in obese adults. Horm Res 1999;51:78-84.

53. Kunitomi M, Wada J, Takahasi K, et al. Relationship between reduced serum IGF-I levels and accumulation of visceral fat in Japanese men. Int J Obes 2002;26:361-9. 
54. Langendonk JG, Meinders AE, Burggraaf J, et al. Influence of obesity and body fat distribution on growth hormone kinetics in humans. Am J Physiol 1999;277:E824-9.

55. Leung DW, Spencer SA, Cachoianes G, et al. Growth hormone receptor and serum binding protein: purification, cloning and expression. Nature. 1987;330:537-543.

56. Makimura H, Stanley T, Mun D, You SM, Grinspoon S. The effects of central adiposity on growth hormone $(\mathrm{GH})$ response to GH-releasing hormone-arginine stimulation testing in men. J Clin Endocrinol Metab 2008;93:4254-4260,.

57. Molitch ME, Clemmons DR, Malozowski S, Merriam GR, Shalet SM, Vance ML for The Endocrine Society's Clinical Guidelines Subcommittee: Evaluation and treatment of adult growth hormone deficiency: An Endocrine Society Clinical Practice Guideline J Clin Endocrinol Metab 2006;91:1621-1634.

58. Münzer T, Harman SM, Hees P, et al. Effects of GH and/or sex steroid administration on abdominal subcutaneous and visceral fat in healthy aged women and men. J Clin Endocrinol Metab 2001;86:3604-3610.

59. Møller N, Copeland KC, Nair KS. Growth hormone effects on protein metabolism. Endocrinol Metab Clin N Am 2007;36:89-100.

60. Mårin P, Kvist H, Lindstedt G, Sjöström L, Björntorp P. Low concentrations of insulin-like growth factor-I in abdominal obesity. Int J Obes 1993;17:83-89.

61. Nam SY, Lee EJ, Kim KR, et al. Effect of obesity on total and free insulin-like growth factor (IGF)1, and their relationship to IGF-binding protein (BP)-1, IGFBP-2, IGFBP-3, insulin, and growth hormone. Int J Obes 1997;21;355-9.

62. Nam SY, Kim KR, Cha BS, et al. Low-dose growth hormone treatment combined with diet restriction decreases insulin resistance by reducing visceral fat and increasing muscle mass in obese type 2 diabetic patients. Int J Obes 2001;25:1101-1107.

63. Nyomba BLG, Johnson M, Berard L, Murphy LJ. Relationship between serum leptin and the insulinlike growth factor-I system in humans. Metabolism 1999;48:840-4. 
64. Nørrelund H, Borglum J, Jorgensen JO, et al. Effects of growth hormone administration on protein dynamics and substrate metabolism during 4 weeks of dietary restriction in obese women. Clin Endocrinol 2000;52:305-312.

65. Peiris AN, Sothman MS, Hoffmann RG, et al. Adiposity, fat distribution and cardiovascular risk. Ann Intern Med 1989;110:867-872.

66. Pasarica M, Zachwieja JJ, DeJonge L, Redman S, Smith SR. Effect of growth hormone on body composition and visceral adiposity in middle-aged men with visceral obesity. J Clin Endocrinol Metab 2007;92;4265-4270.

67. Raben M, Hollenberg C. Effects of growth hormone on plasma fatty acids. J Clin Invest $1959 ; 38: 484-488$.

68. Rasmussen MH, Frystyk J, Andersen T, Breum L, Christiansen JS, Hilsted J. The impact of obesity, fat distribution and energy restriction on insulin-like growth factor-1 (IGF-1), IGF-binding protein-3 and growth hormone. Metabolism 1994;43:315-319.

69. Rasmussen MH, Juul A, Kjems LL, Skakkebæk NE, Hilsted J. Lack of stimulation of 24-hour growth hormone release by hypocaloric diet in obesity. J Clin Endocrinol Metab 1995;80;796-801.

70. Rasmussen MH, Hvidberg A, Juul A, Main KM, Gotfredsen A, Skakkebæk NE, Hilsted J. Massive Weight loss restores 24-hour growth hormone release profiles and serum insulin-like growth factor-I levels in obese subjects. J Clin Endocrinol Metab 1995;80:1407-1415.

71. Rasmussen MH, Ho KYY, Kjems LL, Hilsted J. Serum growth hormone binding protein in obesity: Effect of short term very low calorie diet and diet induced weight loss. J Clin Endocrinol Metab. 1996;81:1519 1524.

72. Rasmussen MH, Juul A, Kjems LL, Hilsted J. Effects of short-term caloric restriction on circulating free insulin-like growth factor (IGF)-I, acid-labile subunit, IGF- binding protein (IGFBP)-1, -2, -3, 4, and IGFBP-1, -2, -3, protease activity in obese subjects. Eur J Endocrinol 2006;155:575-581.

73. Rasmussen MH, Juul A, Hilsted J. Effect of weight loss on free insulin-like growth factor-I in obese women with hyposomatotropism. 2007;15:879-886. 
74. Rasmussen MH, Wildschiødtz G, Juul A, Hilsted J. Polysomnographic sleep, growth hormoneinsulin-like growth factor-I axis, leptin and weight loss. Obesity 2008;16:1516-1521.

75. Ricart W, Fernandez-Real JM. No decrease in free IGF-I with increasing insulin in obesity-related insulin resistance. Obes Res 2001;9:631-6.

76. Richelsen B, Pedersen SB, Borglum JD, Moller-Pedersen T, Jorgensen J, Jorgensen JO. Growth hormone treatment of obese women for 5 wk: effect on body composition and adipose tissue LPL activity. Am J Physiol 1994;266:E211-E216.

77. Richelsen B, Pedersen SB, Kristensen K, et al. Regulation of lipoprotein lipase and hormonesensitive lipase activity and gene expression in adipose and muscle tissue by growth hormone treatment during weight loss in obese patients. Metab Clin Exp 2000;49:906-911.

78. Rosenfeld RG. Growth hormone deficiency in children. In: Endocrinology (Degroot LJ, Jameson JL, Eds.), 2001, 4th edition, W.B. Saunders, pp. 503-519.

79. Satorio S, Malffiuletti NA, Agosti F, et al. Body mass reduction markedly improves muscle performance and body composition in obese females aged 61-75 years: comparison between the effects exerted by energy-restricted diet plus moderate aerobic-strength training alone or associated with rGH or nandrolone. Eur J Endocrinol 2004;150:511-515.

80. Salomon F, Cuneo R, Hesp R, Sönksen P. The effects of treatment with recombinant human growth hormone on body composition and metabolism in adults with growth hormone deficiency. $\mathrm{N}$ Engl $\mathrm{J}$ Med 1989;321:1221-1225.

81. Sandhu MS, Heald AH, Gibson JM, Cruickshank JK, Dunger DB, Warreham NJ. Circulating concentrations of insulin-like growth factor-I and development of glucose intolerance: a prospective observational study. Lancet 2002;359:1740-5.

82. Shadid S, Jensen MD. Effects of growth hormone administration in human obesity. Obes Res 2003;11:170-175. 
83. Simpson H, Savine R, Sönksen P, Bengtsson BA, Carlsson L, Christiansen JS, Clemmons D, Cohen P, Hintz R, Ho K, Mullis P, Robinson I, Strasburger C, Tanaka T, Thorner M. * GRS Council. Growth hormone replacement therapy for adults: into the new millennium. Growth Horm IGF Res, $2002 ; 12: 1-33$.

84. Skaggs SR, Crist DM. Exogenous human growth hormone reduces body fat in obese women. Horm Res 1991;35:19-24.

85. Smith SR, Zachwieja JJ. Visceral adipose tissue: a critical review of intervention strategies. Int J Obes Relat Metab Disord. 1999;23:329-335.

86. Snyder DK, Clemmons DR, Underwood LE. Treatment of obese, diet-restricted subjects with growth hormone for 11 weeks: effects on anabolism, lipolysis, and body composition. J Clin Endocrinol Metab 1988;67:54-61.

87. Snyder DK, Clemmons DR, Underwood LE. Dietary carbohydrate content determines responsiveness to growth hormone in energy-restricted humans. J Clin Endocrinol Metab 1989;69:745-752.

88. Snyder DK, Underwood LE, Clemmons DR. Anabolic effects of growth hormone in obese dietrestricted subjects are dose dependent. Am J Clin Nutr 1990;52:431-437.

89. Snyder DK, Underwood LE, Clemmons DR. Persistent lipolytic effect of exogenous growth hormone during caloric restriction. Am J Med 1995;98:129-134.

90. Street ME, Ziveri MA, Spaggiari C, et al. Inflammation is a modulator of the insulin-like growth factor (IGF)/IGF-binding protein system inducing reduced bioactivity of IGFs in cystic fibrosis. Eur J Endocrinol 2006;154:47-52.

91. Taaffe DR., Pruitt L., Reim J, et al. Effect of recombinant human growth hormone on the muscle strength response to resistance exercise in elderly men. J Clin Endocrinol Metab 1994;79:1361-1366.

92. Taaffe DR, Thompson JL, Butterfield GE, Hoffman AR, Marcus R. Recombinant human growth hormone, but not insulin-like growth factor-I enhances central fat loss in postmenopausal women undergoing a diet and exercise program. Horm Metab Res 2001;33:156-162. 
93. Tagliaferri M, Scacchi M, Pincelli AI, et al. Metabolic effects of biosynthetic growth hormone treatment in severely energy-restricted obese women. Int J Obes 1998;22:836-841.

94. Tankó LB, Bruun JM, Alexandersen P, Bagger YZ, Richelsen B, Christiansen C, Larsen PJ. Novel associations between bioavailable estradiol and adipokines in elderly women with different phenotypes of obesity: implications for atherogenesis. Circulation 2004 110:2246-2252.

95. Thompson JL, Butterfield GE, Gylfadöttir UK, et al. Effects of human growth hormone, insulin-like growth factor I, and diet and exercise on body composition of obese postmenopausal women. J Clin Endocrinol Metab 1998;83:1477-1484.

96. Utz AL, Yamamoto A, Hemphill L, Miller KK. Growth hormone deficiency by growth hormone releasing hormone-arginine testing criteria predicts increased cardiovascular risk markers in normal young overweight and obese women. J Clin Endocrinol Metab 2008;93:2507-25149.

97. Vance ML, Mauras N. Growth hormone therapy in adults and children. N Eng J Med 1999;341:1206- 1214.

98. Veldhuis JD, Iranmanesh A, Ho KK, Waters MJ, Johnson MI, Lizzarralde G. Dual defects in pulsatile growth hormone secretion and clearance subserve the hyposomatotropism of obesity in man. J Clin Endocrinol Metab 1991;72:51-59.

99. Weaver JU, Monson JP, Noonan K, et al., The effect of low dose recombinant human growth hormone replacement on regional fat distribution, insulin sensitivity and cardiovascular risk factors in hypopituitary adults. J Clin Endocrinol Metab 1995;80:153-159.

100. Whitehead H, Boreman C, Mcllrath E, et al. Growth hormone treatment of adults with growth hormone deficiency: results of a 13-month placebo-controlled cross-over study Clin Endocrinol $1992 ; 36: 45-52$

101. Yuen K, Ong K, Husbands S, Chatelain P, Fryklund L, Gluckman P, Ranke M, Cook D, Rosenfeld R, Wass J, Dunger D. The effects of short-term administration of two low doses versus the standard GH replacement dose on insulin sensitivity and fasting glucose levels in young healthy adults 2002;87:1989-1995. 